75 巻 755 号 $(2009-7)$

\title{
重合メッシュ法を用いた疲労き裂進展シミュレーション*
}

（第 3 報, 三次元表面き裂進展シミュレーション）

\author{
菊 池 正 紀 ${ }^{* 1}$, 和 田 義 孝*2 \\ 宇都宮篤 ${ }^{* 3}$, 須山ひとみ*3
}

\section{Fatigue Crack Growth Simulation Using S-Version FEM (3rd Report, Fatigue of 3D. Surface Crack)}

\author{
Masanori KIKUCHI*4, Yoshitaka WADA, \\ Atsushi UTSUNOMIYA and Hitomi SUYAMA \\ ${ }^{* 4}$ Department of Mechanical Engineering, Tokyo University of Science, \\ 2641 Yamazaki, Noda-shi, Chiba, 278-8510 Japan
}

\begin{abstract}
Fatigue crack growth under mixed mode loading conditions is simulated using S-FEM. By using S-FEM technique, only local mesh should be re-meshed and it becomes easy to simulate crack growth. By combining with re-meshing technique, local mesh is re-meshed automatically, and curved crack path is modeled easily. Fully automatic crack growth simulation system in 3-dimensional problem is developed. At first, a basic slant surface crack problem is solved, and it is shown that surface crack grows under pure mode I conditions, which is similar in 2-dimensional problem. It is also shown that this system is available for complicated structure, for example, surface crack at inner surface of pipe. Finally, interaction effect of two surface cracks is evaluated.
\end{abstract}

Key Words: Fatigue Fracture, Crack Growth, S-Version FEM, VCCM, Auto-Mesh, Mixed Mode

\section{1. 緒言}

機器・部品の健全性を確保することは機械技術の重 要な課題のひとつである. 特に疲労破壊は機器の破壊・ 損傷の原因の $80 \%$ 以上を占めることから，疲労破壊 に対する評価は重要である. 疲労破壊は通常, 機器の 応力集中部を基点として発生し，長期間のうちに徐々 に進展してゆく．そのため微小な疲労き裂の検出とそ の進展予測が重要な技術となっている.こうした問題 で疲労き裂の進展を評価するには，有限要素法 (FEM) による応力解析とそれに基づいた応力拡大係数の評 価が不可欠となる，しかし時々刻々と形状が変化する 疲䟫き裂に対してこれを行うためにはき裂を含む構造 全体の有限要素モデルを毎回更新する必要がある。こ れはきわめて煩雑な作業であり，現実的な問題には簡 単には対処できない，そこでこうした問題を解决する ために，メッシュモデル作成を容易にする研究が多数 行われてきた. 例えばエレメントフリーガラーキン法 (1), フリーメッシュ法(2), X-FEM ${ }^{(3)}$, 重合メッシュ法 $(\mathrm{S}-\mathrm{FEM})^{(4)}$ などである.

* 原稿受付 2009 年 1 月 28 日.

*1 正員, フェロー, 東京理科大学理工学部機械工学科(画 2788510 野田市山崎 2641)。

*2 正員, 諏訪東京理科大学システム工学部機械システムデザイ ン工学科 (画 391-0292 茅野市豊平 5000-1).

*3 東京理科大学大学院理工学研究科機械工学専攻.

E-mail : kik@me.noda.tus.ac.jp
著者らは上記のさまざまな方法のうち重合メッシュ 法に着目し，これを自動メッシュ技術と組み合わせる ことにより, 二次元問題に対して複雑な荷重下で, ま た複雑な形状の中での疲労き裂進展を自動的にシミュ レーションすることのできるシステムを構築した ${ }^{(5)(6)}$. 第一報 ${ }^{(5)}$ ではこのシステムを二つの平行き裂の相互干 涉問題に適用し, 日本機械学会の維持規格 ${ }^{(7)}$ との比較 を行った．第二報(6)では上記の問題をさらに詳細に検 討して，二つのき裂の相互干涉効果を判定する新たな 基準を提案した. 本報告はこの技術を三次元問題に拡 張し，いくつかの例題を解析した結果を報告する. 問 題が三次元になることで, 応力拡大係数の混合モード 成分として $K_{I}, K_{I I}$ 成分の他に $K_{I I I}$ を考慮する必要が 出てくる．これらを用いてき裂進展方向，き裂進展速 度を決定し，新たなき裂形状を三次元的に決定し，そ れを自動メッシュ技術を用いてモデル化する．これに より，完全に自動的な三次元疲労き裂進展シミュレー ションシステムができた。本報告では三次元問題での 自動メッシュ技術，き裂進展クライテリオンについて 説明した後, 簡単な例題を解析してこのシステムの有 効性を示す．また二つの表面き裂が相互干涉しながら 進展する問題を解析し, 日本機械学会規格との比較を 行った結果について述べる. 


\section{2. 三次元場での重合メッシュ法による 疲労き裂進展シミュレーション}

重合メッシュ法についてはすでに第一報(5)で説明し ているのでここでは説明を省略する. 三次元場で疲労 き裂進展シミュレーションを行ううえで, 二次元問題 と異なる点は, き裂進展クライテリオン, 複雑形状で のローカルモデルの自動メッシュ生成技術, の二つで ある. 以下ではこれらについて簡単に説明する.

\section{$2 \cdot 1$ 三次元疲労き裂進展クライテリオン 二次} 元問題では混合モード条件化で考慮すべき応力拡大 係数は $K_{I}$ と $K_{I I}$ のみであり，これを用いてき裂進展 方向を予測し, また等価応力拡大係数を定義して進展 速度を予測する手法はすでに多くの研究が行われて おり，ほぼ確定しているということができる．しかし 三次元問題では $K_{I I I}$ を含めたクライテリオンが必要 となる.これに関してはいくつかのクライテリオンが 提案されているが，確定したものはまだない，たとえ ば等価応力拡大係数の定義としては, $\mathrm{Sih}^{(8)}$, Pook $^{(9)}$, Schollmann ${ }^{(10)}$, Richard ${ }^{(11)}$ らがそれぞれ提案している. き裂進展方向のクライテリオンについては, 最大接線

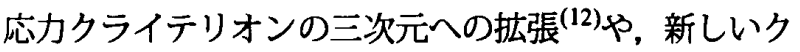
ライテリオンが提案されるなど，やはり複数の提案が されている(8)(9)(10)(11).

本研究では等価応力拡大係数, き裂進展方向ともに Richard ${ }^{(11)}$ らによって提案された下記のクライテリオ ンを用いることとした. このクライテリオンは二次元

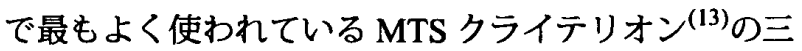
次元への払張であるため信頼性が高いと判断した. 式 中のき裂進展方向 $\varphi_{0}, \psi_{0}$ の定義を図 1 k示す.

$$
K_{e q}=\frac{K_{I}}{2}+\frac{1}{2} \sqrt{K_{I}^{2}+4\left(\alpha_{1} K_{I I}\right)^{2}+4\left(\alpha_{2} K_{I I I}\right)^{2}}
$$

ここで $\alpha_{1}=1.155, \alpha_{2}=1.0$ である.

$\varphi_{0}=\mp\left[A \frac{\left|K_{I I}\right|}{K_{I}+\left|K_{I I}\right|+\left|K_{I I I}\right|}+B\left(\frac{\left|K_{I I}\right|}{K_{I}+\left|K_{I I}\right|+\left|K_{I I I}\right|}\right)^{2}\right]$

ここで $K_{I I}>0$ に対しては $\varphi_{0}<0^{\circ}$ とし, $K_{I I}<0$, $K_{I} \geq 0$ に対しては $\varphi_{0}>0^{\circ}$ の值をとるものとする. ま た $A=140^{\circ}, B=-70^{\circ}$ である.

$\psi_{0}=\mp\left[C \frac{\left|K_{I I I}\right|}{K_{I}+\left|K_{I I}\right|+\left|K_{I I I}\right|}+D\left(\frac{\left|K_{I I I}\right|}{K_{I}+\left|K_{I I}\right|+\left|K_{I I I}\right|}\right)^{2}\right]$
ここで $K_{I I I}>0$ に対しては $\psi_{0}<0^{\circ}$ とし， $K_{I I I}<0$, $K_{I} \geq 0$ に対しては $\psi_{0}>0^{\circ}$ の值をとるものとする. ま た $C=78^{\circ}, D=-33^{\circ}$ である.

しかしながら本研究では, 式 (3) は用いていない. その理由は $\psi_{0}$ を考慮した場合，図 1 のようにき裂面 がねじれて不連続になるためメッシュ生成が困難にな るためである.このとき,き裂先端は不連続に折れ曲 がりながら連結する, いわゆるファクトリールーフの 形状を形成することになる. それを正確にモデル化す るには,今より数倍以上大きな要素・節点数を扱わな いと不可能であり, 現在のコンピュータの能力を超え ている.この問題の詳細な検討は将来の課題である.

なお以下に示す解析では, 材料はすべてアルミニウム 合金を想定し，パリス則の定数として $C=3.66 \times 10^{-14}$, $n=2.37$ を用いた. これは応力比 $\mathrm{R}=0.1$ で行われた実 験結果に基づいて決定した.ここで, $d a / d N$ の単位は $[\mathrm{mm} /$ cycle $], \Delta K_{e q}$ の単位は $\left[\mathrm{MPa} \cdot \mathrm{m}^{1 / 2}\right]$ である. 疲労 き裂進展評価の際はき裂の開閉口挙動を考慮する必要 があるが,これは非線形挙動であるため,その正確な評 価のためには弾塑性解析を必要とする.ここでは弾性 解析のみで簡便に評価を行うために.き裂閉口を考慮 せずにき裂進展解析を実施した。

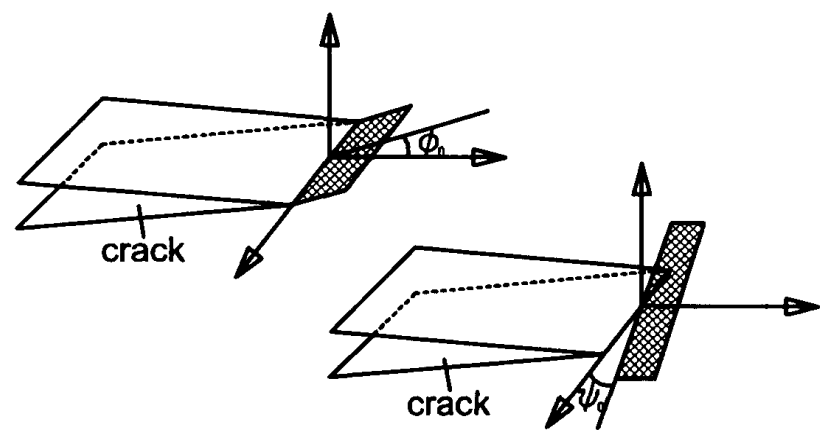

Fig. 1 Crack growth direction.

\section{2 複雑形状におけるローカルメッシュの自䣦作成} 技術き裂を含む構造物が複雑な形状をしていると き，表面き裂は表面ではその複雑な形状に沿って進展 する.ここで用いている重合メッシュ法では, き裂を含 む領域をローカル領域として自動要素分割し，グロー バルメッシュに重ねて使用するので，構造表面部では 両者の表面形状が一致している必要がある. ローカル メッシュは疲労き裂の進展につれてその形状を変化さ せてゆくが, 表面部分で常にグローバルメッシュと一 致しなくてはならない，例として, グローバルメッシュ が図 2 に示すような球形の場合, 重ね合わせるローカ ルメッシュは，構造物表面部分では常に球状表面の一 部となっていなければならない。 
このようなローカル要素を作成するためには, 表面 の形状データが必要である. しかし複雑な形状では表 面の形状をデータとして与えることが容易でない．そ こでグローバルメッシュに注目した．重合メッシュ法 では，構造物全体を表現するグローバルメッシュを必 ず用意する必要があり，これは形状データを有してい る. そこでこれを利用して, グローバルメッシュの表面 を探しながら，表面を一致させるようにローカルメッ シュを作成するような, 自動要素分割ソフトを作成し た.これによって,どのような複雑な形状でも，グロー バルメッシュでその形状が表現できるなら，ローカル メッシュの自動作成については特別の配慮を必要とし ないシステムが完成した。

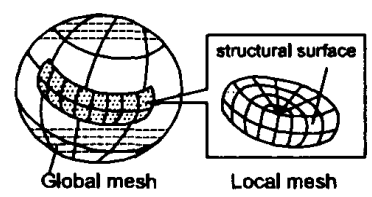

Fig. 2 Shape of Local mesh when Global mesh is complex.

\section{3. 斜め表面き裂の疲労進展解析}

以上のように作成したシステムを用いて図 3 に示す ような斜め表面き裂の疲労進展解析を行った. 表面き裂 は図に示すように, 応力軸との直角方向に対して $30^{\circ}$ 傾 いているものとする. 初期き裂寸法は $2 c_{0}=3.0[\mathrm{~mm}]$ とし，アスペクト比 $a / c=0.5$ とした. その他の寸 法は図中に示している。この表面き裂を含む厚板に $\Delta \sigma=9[\mathrm{MPa}]$ の応力振幅を与えた. ここで, き裂を図 のように $x-y$ 面に投影したときのき裂長さを $c^{\prime}$, き 裂深さを $a^{\prime}$ と定める. またき裂進展開始前の $c^{\prime}$ を $c_{0}^{\prime}$ と表す. 図4にグローバルメッシュと初期き裂のロー カルメッシュを示す. グローバルメッシュは全体に均 一に要素分割している. 重合メッシュ法ではグローバ ルメッシュとローカルメッシュの間の要素の整合性を 考慮する必要がないため, この斜めき裂モデルは図 3 の $x-y$ 平面に対して平行なき裂データを, $y$ 軸につい て $30^{\circ}$ 回転させるだけで作ることができる.

図 5 にき裂の進展に伴うき裂形状の変化を示す. 図 中にはき裂の初期状態， $x-y$ 面に投影したき裂長さが 二倍，三倍になったときのき裂面が表されている．き 裂面を構成する周方向のエッジは進展の履歴を表す. き裂進展のごく初期から斜めき裂はき裂表面近傍で大 きく進展方向を変えている. そして最終的に与えられ た応力に対して直角方向にフラットになるという結果
を得た.

き裂進展に伴う $K_{I I}, K_{I I I}$ の変化を $K_{I}$ で無次元化し て図 6，7に示す．図の $\theta$ は図 3 に示すようにき裂を $x-y$ 面に投影し，き裂前縁の離心角をとったものであ る. 進展開始直後 $\left(c^{\prime}=1.1 c_{0}^{\prime}\right)$ k, 表面付近の $K_{I I} / K_{I}$ が大きく減少している.これは，図5 5 かわかるよう に表面付近でき裂が大きく進展方向を変えたことによ る. 一方 $K_{I I I} / K_{I}$ は進展開始直後には大きな変化が見 られないが, その後進展とともに滅少してゆく. 進展 とともに $K_{I I} / K_{I}, K_{I I I} / K_{I}$ はゼロに近づいてゆき，き 裂はモードIで進展するという結果を得た．これは二 次元問題の解析結果 ${ }^{(5)}$ と同様である.

このときの応力拡大係数 $K_{I}$ の変化を図 8 に示す. $K_{I}$ は初期状態ではき裂底部分の值が最大となっている. しかし進展開始直後にき裂の表面部分の $K_{I}$ の值が上 昇し，その後は $K_{I}$ はき裂前縁でほぼ一様な值をとる ように進展した。

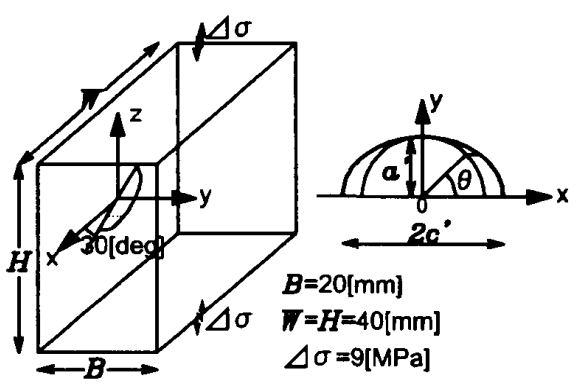

Fig. 3 Slant crack problem.

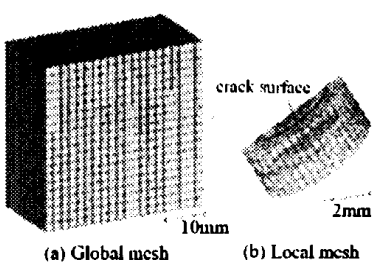

Fig. 4 Slant crack models.

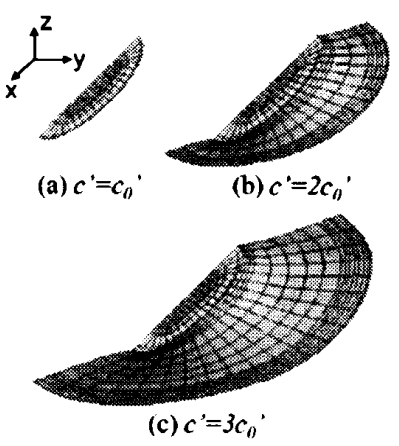

Fig. 5 Crack growth behavior. 


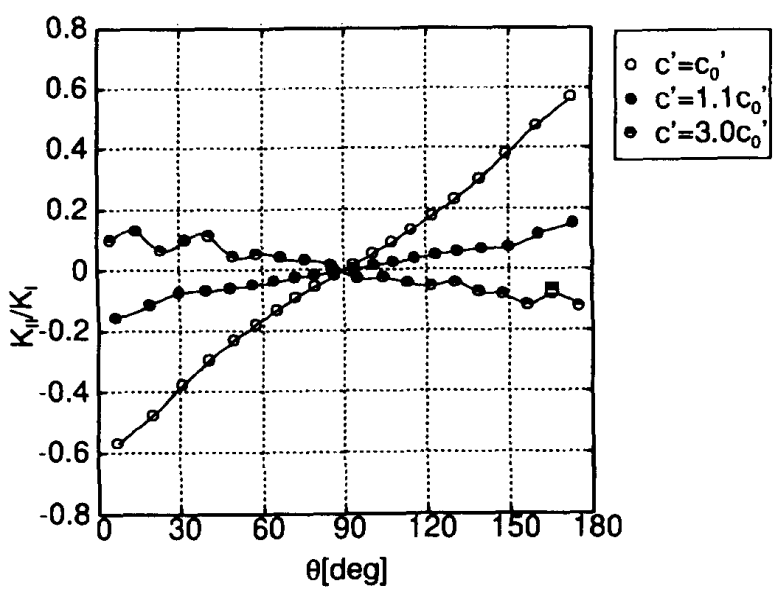

Fig. 6 Mode ratio $K_{I I} / K_{I}$.

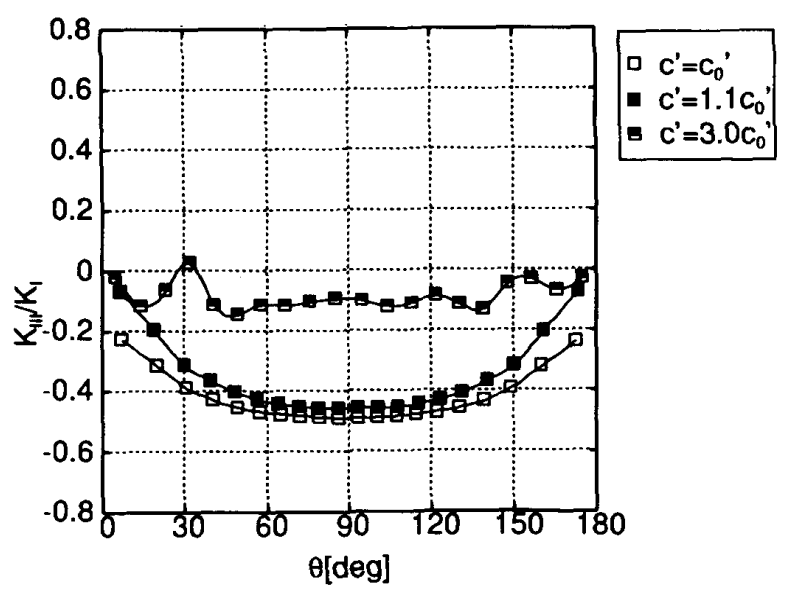

Fig. 7 Mode ratio $K_{I I I} / K_{I}$.

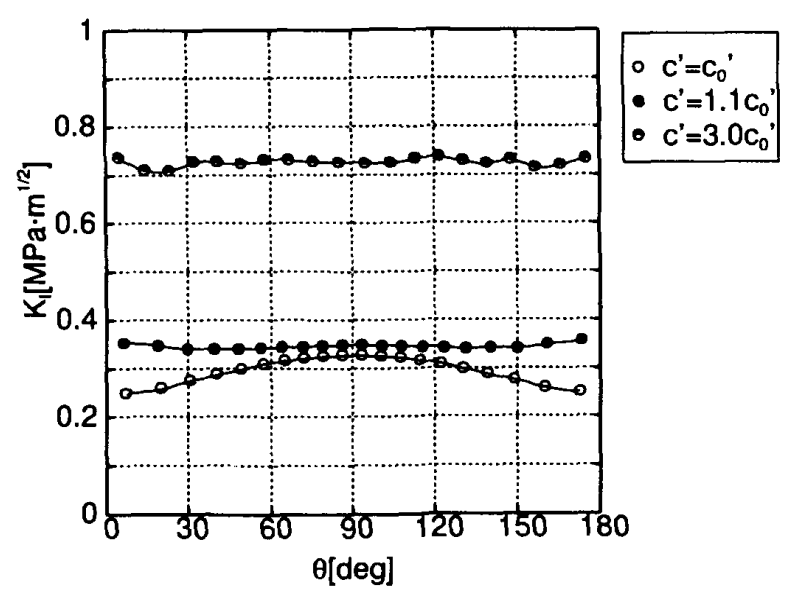

Fig. 8 Stress intensity factor $K_{I}$.

\section{4. 複雑形状部での表面き裂進展解析}

複雑形状の例として, 図9のようなパイプ内壁に存 在するき裂の進展解析を示す. 初期き裂寸法は $2 c_{0}=$ $4.0[\mathrm{~mm}]$ とし,アスペクト比 $a / c=0.5$ とした. その他
の寸法は図中に示している. このパイプに $\Delta \sigma=9[\mathrm{MPa}]$ の応力振幅を与えた。この場合ローカルメッシュは図 10 に示すように, グローバルの外形と一致するよう に表面部分が曲面になったものが生成される．図11 にこのときのき裂形状の変化を示す．き裂は進展開始 $\left(c=c_{0}\right)$ からき裂底部分がき裂表面部分に比べて大き く進展し，その後き裂前粶でほぼ一定に進展し続けた。 図 12 には応力拡大係数 $K_{I}$ の変化を示す. 図 12 の横軸 には図 9 に示すようにき裂の表面部分を結んだべクト ルを $x$ 軸，それに直角な方向を $y$ 軸としたときのき裂 の離心角をとる．き裂は負荷に対して直角方向に存在 するので，モードIで進展する．初期状態ではき裂底 の $K_{I}$ が最大である. 進展によりき裂表面部分の $K_{I}$ の 值が上昇し， $K_{I}$ の值はき裂前縁でほぼ一様になった. これは斜めき裂の解析結果と同様であり，き裂が応力 拡大係数 $K_{I}$ がほぼ一様となるように進展するという 結果となった.

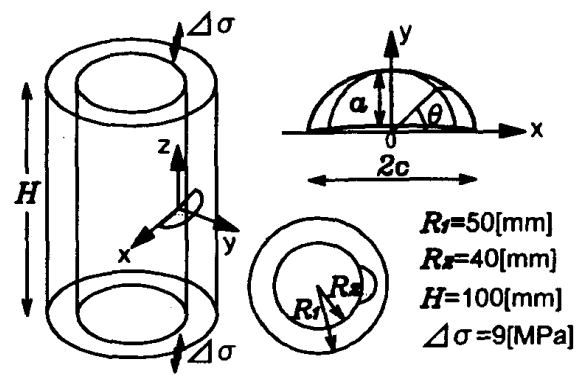

Fig. 9 The problem at the inner surface of Pipe.

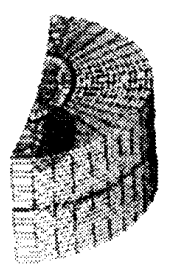

Fig. 10 Local mesh at the inner surface of Pipe.

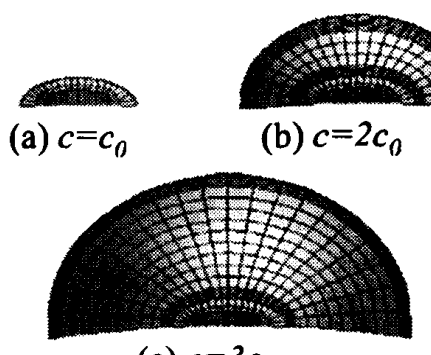

(c) $c=3 c_{0}$

Fig. 11 Crack growth behavior. 


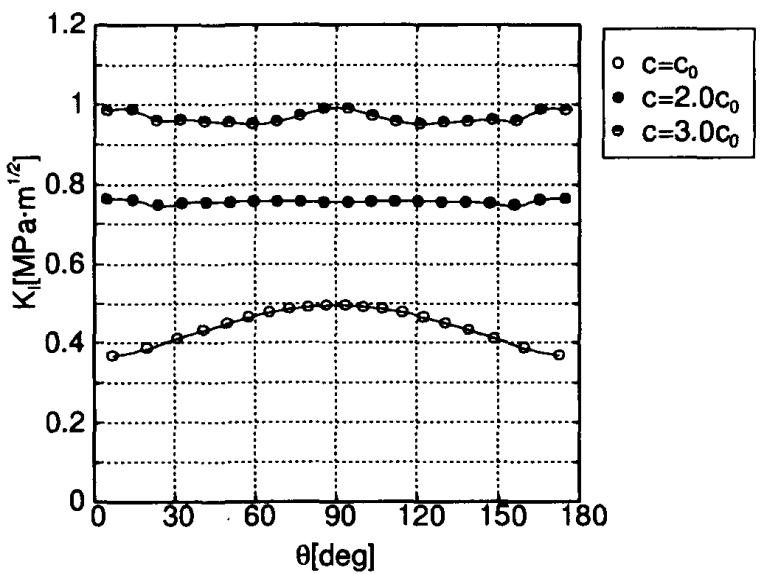

Fig. 12 Stress intensity factor $K_{I}$.

\section{5. 二つの表面き裂の相互干渉評価}

二つの並行段違いき裂について，き裂間の相互干涉 効果と合体条件についてクライテリオンが提案されて いる. 図 13 に示された二つの段違いき裂のき裂先端 間の水平距離を $S$, 垂直方向の距離を $H$ であらわす. 日本機械学会による原子力維持規格 ${ }^{(7)}$ では $S$ と $H$ が 式 (4)の関係を満たすとき, 二つのき裂を同一平面状 にある複数き裂として取り扱い，進展により $S=0$ に なった時点で段違いき裂は合体したものと判断するよ うに定められている. 合体したき裂は図 14 のように 取り扱う．また，き裂が $S>0$ ではそれぞれ単独なき 裂として取り扱うこととしている.

$$
\begin{array}{lll}
S \leq 5 m m & \text { and } & H \leq 10 m m \\
S>5 m m & \text { and } & H \leq 2 S
\end{array}
$$

この規格を参考にして，初期のき裂間距離位置 $S_{0}$ と $H_{0}$ を表 1 に示すように設定した 2 つのケースにつ いて疲労き裂進展解析を行い, き裂の相互干渉効果に ついて考察する.

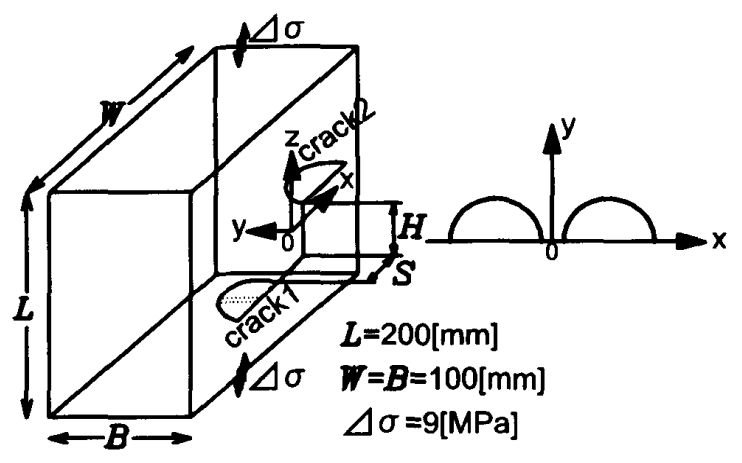

Fig. 13 Plural crack problem.

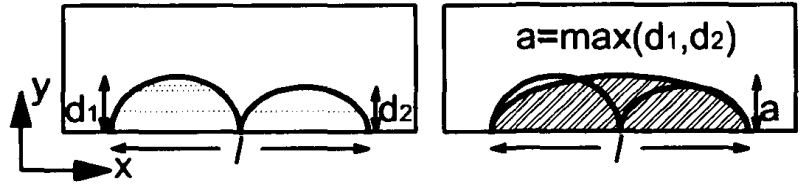

Fig. 14 Coalescence crack.

Table $1 \quad S_{0}$ and $H_{0}$ values for each case.

\begin{tabular}{|l||c|c|}
\hline & $S_{0}[\mathrm{~mm}]$ & $H_{0}[\mathrm{~mm}]$ \\
\hline \hline Case1 & 3 & 1 \\
\hline Case2 & 3 & 3 \\
\hline
\end{tabular}

図 15には Casel のき裂形状の変化を示す. 図中の $S$ の值は $2 つ の$ 表面き裂間距離であり, き裂進展につ れてこの値は小さくなってゆく. $S<0$ の場合は両者 がオーバーラップしていることを示す. 初期状態では き裂はまっすぐ進展してゆく. その後き裂が接近する にしたがって互いのき裂先端に近い内側表面部の進展 方向が変化し，(c)に示すように互いのき裂が接近す る. また, 図 16 にそのときの忘力拡大係数 $K_{I}$ の変化 を表す. 図 16 の横軸にはき裂を $x-y$ 面に投影し，そ の $x$ 座標を取る。

(a) $S=3.0$

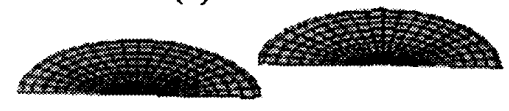

(b) $S=0.3$

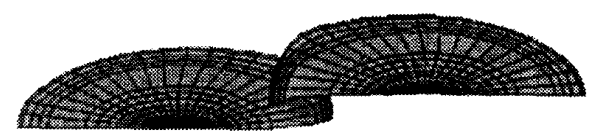

(c) $S=-1.6$

Fig. 15 Plural crack growth behavior (Case1).

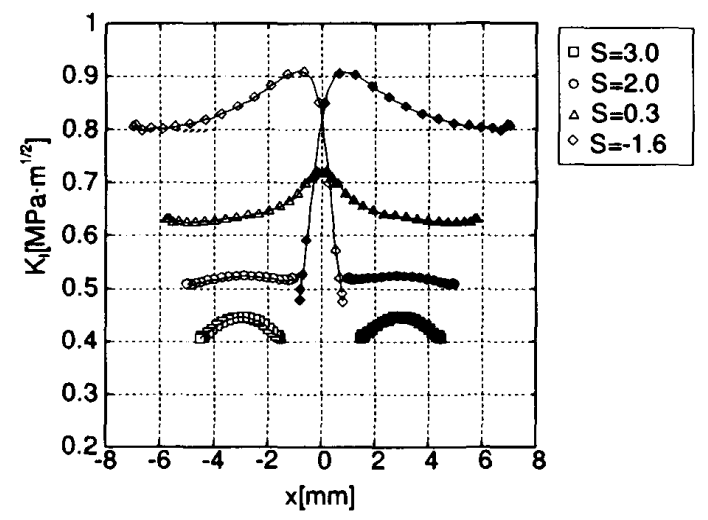

Fig. 16 Casel $K_{I}$. 
二つのき裂はまず $K_{I}$ が一定となるように進展する. そしてき裂が接近するにしたがって，互いのき裂先端 に近い内側表面部の $K_{I}$ が増加してゆく.き裂がオー バーラップすると応力緩和の影響で内側表面部の $K_{I}$ は減少し, 代わりに $x=0$ 近傍の $K_{I}$ が最大となるこ とが分かる. Case2 の $K_{I}$ の変化について図 17 に示す. Case2では Case1 と異なり，二つのき裂が接近しても， 内側表面部の $K_{I}$ の増加が見られなかった. オーバー ラップ後も $K_{I}$ が最大となる箇所は見られず, オーバー ラップ部以外はほぼ一様な $K_{I}$ の值をとる. しかしき 裂がオーバーラップした際の応力緩和の影響は見られ, $K_{I}$ が減少している.

$S \leq 0$ では Case1, Case2 ともに式 (4)を満たすため 合体き裂として取り扱うが. その際に $H$ は考慮され ていないため二つのケースが考える合体き裂は同じに なる. しかし $H$ の違いで $K_{I}$ の分布へこのような影響 が見られることがわかった.

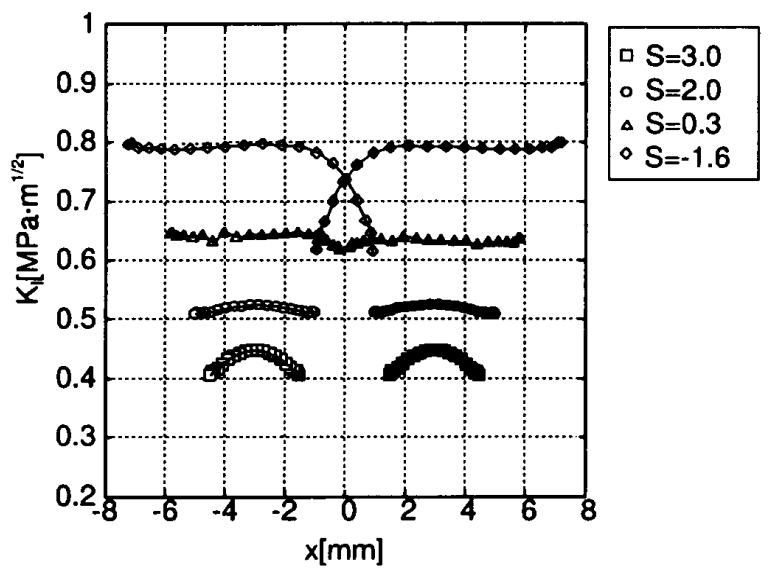

Fig. 17 Case2 $K_{I}$.

以下では Casel に注目して二種類の応力拡大係数 を比較する. 初期状態から複数き裂を進展解析した ものと, その進展の途中過程を原子力維持規格に従っ て単独き裂 (single crack) または合体き裂 (coalescence crack) とみなして解析したものである. 図 18 にき裂 が合体と判断される直前の $S=0.2$, 図 19 に合体した 直後の $S=-0.2$ の比較を示す.

合体直前 $(S=0.2)$ では複数き裂は互いの相互作用 でき裂の内側表面部の $K_{I}$ が上昇するため，単独き裂 の解析結果よりも大きくなる. 一方複数き裂の外側表 面部では二つの解析結果はほぼ同じ値をとっている. これは著者らの二次元での結果 ${ }^{(5)(6)}$ とも一致している. その意味ではこのケースでは原子力維持規格の評価は 保守的なものである. しかし合体き裂と見なされた直 後 $(S=-0.2)$ では, 複数き裂の外側表面部の解析結果 が仮想合体き裂表面部の結果より大きな値をとってい
る. 合体直後でなく，さらにき裂が進展した後に評価 をしても, 同じくき裂表面部分で合体き裂の解析解が 小さくなるという結果を得ている. また Case2 や他の ケースでも同様の結果となった。 これは二次元解析で は起こらなかったことである.この理由は複数き裂を 規格に従って合体き裂としてモデル化すると，き裂の 表面部分で曲率が異なることによるものである.

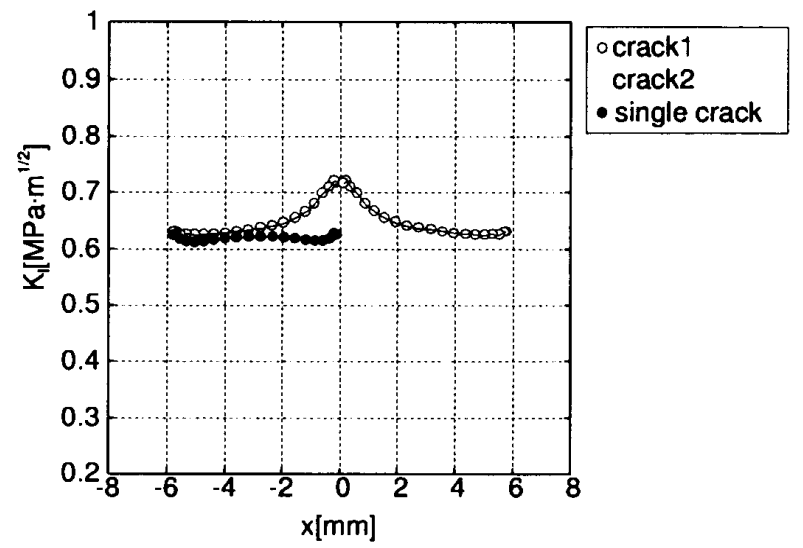

Fig. 18 Plural crack and single crack $(S=0.2)$.

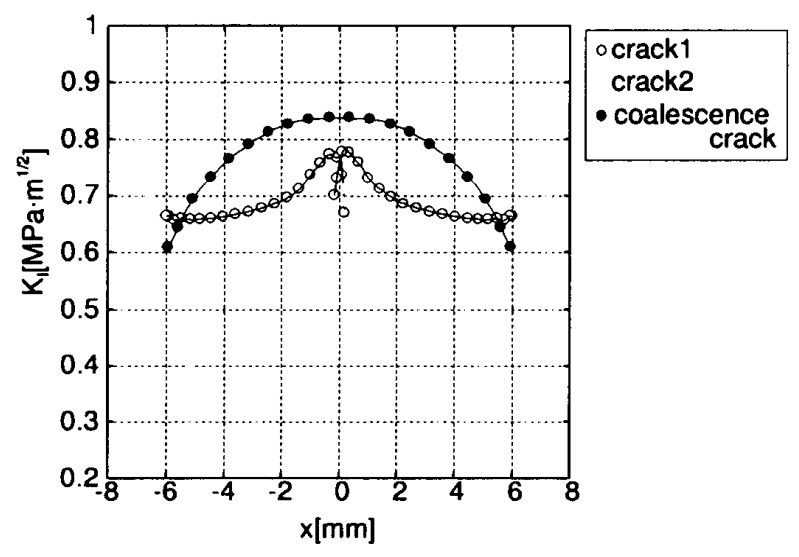

Fig. 19 Plural crack and coalescence crack $(S=-0.2)$.

この結果では規格に従って合体を判断し，合体き裂 によって寿命を判断した場合, き裂表面部分の寿命が 正しく求められない可能性がある. そこで, 以下では $S \leq 0$ を満たした複数き裂を合体き裂としてモデル化 して進展解析し，複数き裂による進展解析と比較する ことにする. 合体の開始は Casel の $S=-0.2$ として, そこから合体き裂の進展解析を行った. 図20は合体き 裂進展開始から $2.8 \times 10^{6}$ Cycles 進み $S=-1.1$ となっ たとき, 図 21 は $6.2 \times 10^{6}$ Cycles 進み $S=-1.6$ となっ たときの複数き裂と合体き裂の态力拡大係数を比較し ている. 合体直後は複数き裂の外側表面部分の $K_{I}$ の 值が合体き裂表面部分の $K_{I}$ の值よりが大きかったが, 
進展してゆくとともに合体き裂表面部分の $K_{I}$ の值が 上昇して最終的には合体き裂表面部分の $K_{I}$ の值が複 数き裂の外側表面部分 $K_{I}$ の值を上回った.このこと から, 複数き裂を合体き裂として取り扱い, 進展解析 をおこなって寿命等を求めた場合, 最終的に保守的に 評価されるということがわかった.

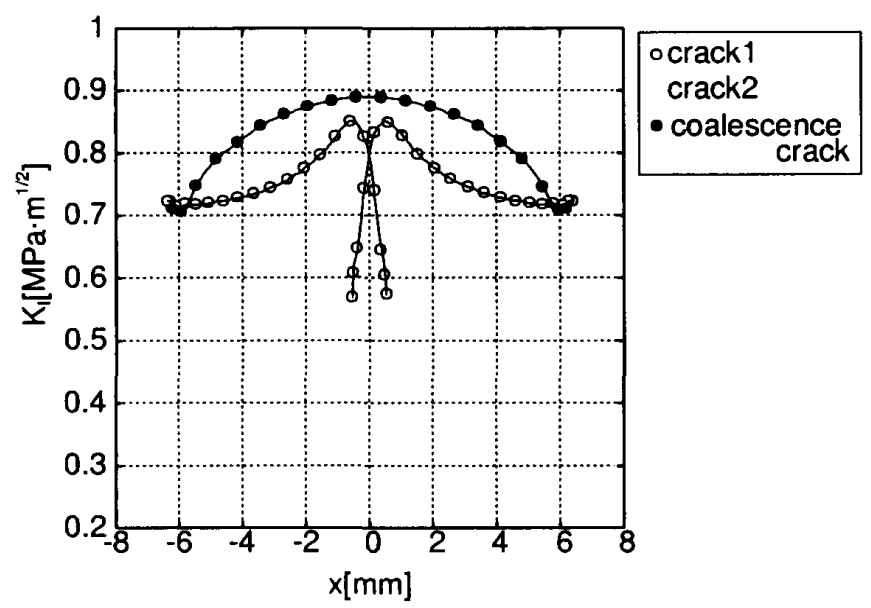

Fig. 20 Coalescence crack growth $(S=-1.1)$.

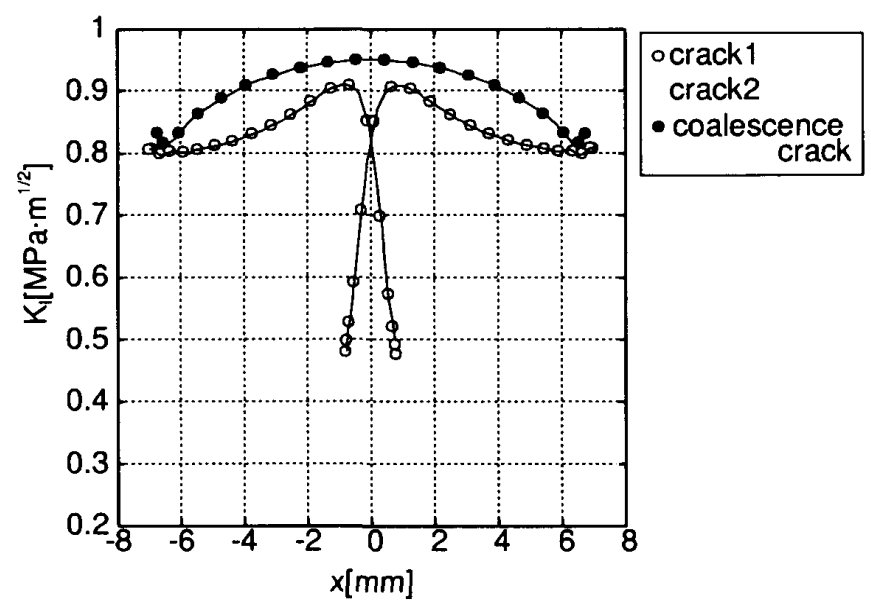

Fig. 21 Coalescence crack growth $(S=-1.6)$.

\section{結言}

(1) 重合メッシュ法による完全に自動な三次元疲労き 裂進展シミュレーションが可能となった.

(2)これを用いて斜め表面き裂やパイプ内壁の表面き 裂など,複雑形状の表面き裂の疲労き裂進展シミュレー ションを行い妥当な結果を得た.

(3)二つの平行な表面き裂の進展評価を行い, 原子力維 持規格と比較した. 原子力維持規格が保守的な評価を していることが確認できた.

\section{文献}

(1) Belytschko,T., Lu,Y.Y., Gu,L., Element-free Galerkin methods, International Journal for Numerical Methods in Engineering, Vol.37, (1994), pp.229-256

(2) Yagawa,G., Yamada,T., Free mesh method: A new meshless finite element method, Computational Mechanics, Vol.18, (1996), pp.383-386

(3) Belytschko,T., Black,T., Elastic Crack Growth in Finite Elements With Minimal Remeshing, International Journal for Numerical Methods in Engineering, Vol.45, (1999), pp.601-620

(4) Fish,J., Markolefas,S., Guttal,R., Nayak,P., On adaptive multilevel superposition of finite element meshes, Applied Numerical Mathematics, Vol.14, (1994), pp.135-164

(5) Kikuchi,M., Wada,Y., Takahashi,M., Li,Y., Fatigue Crack Growth Simulation using S-version FEM, Advanced Materials Research, Vol.33-37, (2008), pp.133-138

(6) Kikuchi,M., Takahashi,M., Wada,Y., Li.Y., Fatigue Crack Growth Simulation using S-Version FEM $2^{\text {nd }}$ report (in Japanese), Transactions of the Japan Society of Mechanical engineers, Series A, Vol.74, (2008), pp.12351242

(7) JSME S Nal-2004, Codes for Nuclear Power Generation Facilities (in Japanese), (2004),

(8) Sih,G.C, Strain-energy-density factor applied to mixed mode crack problems, International Journal of Fracture, Vol.10,No.3, (1974), pp.305-321

(9) Pook,L.P., The significance of mode 1 branch cracks for combined mode failure, Fracture and Fatigue: ElastoPlasticity. Thin Sheet and Micromechanism Problems, (1980), pp.143-153

(10) Schollmann,M., Kullmer,G., Fulland,M., Richard,H.A., A New Criterion for 3D Crack Growth under Mixedmode(I+II+III) Loading, Proceedings of the 6th International Conference on Biaxial/Multiaxial Fatigue and Fracture, Vol.2, (2001), pp.589-596

(11) Richard,H.A., Fulland,M., Sander,M., Theoretical crack path prediction, Fatigue and Fracture of Engineering materials and Structures, Vol.28, (2005), pp.3-12

(12) dell'Erba,D.N., Aliabadi,M.H., Three-dimensional thermo-mechanical fatigue crack growth using BEM, International Journal of Fatigue, Vol.22, (2000), pp.261273

(13) Erdogan and G.C.Sih,On the crack extension in plates under plane loading and transverse shear,Trans.ASME.J.Basic Eng.,Vol.85(1963),pp.519-527 